\title{
Os mais invisíveis do mundo
}

\author{
Leonardo Ortegal
}

Eles estão entre nós. Não são os ET's, e estão invisíveis. Não são pretos, nem putas, mas nos servem como escravos há séculos, e tem seus corpos atravessados, como objetos, para a satisfação de nosso desejo hedonista.

Eles são tratados do jeito que se trata as minorias: suas necessidades são subjugadas, suas dores, menosprezadas, e sua fragilidade se transforma em degraus para que passem em ascensão aqueles que detém o poder. Mas acontece que, como várias minorias, eles não são minoria. Na verdade eles já chegam a ser maioria, como uma manifestação epidêmica da nossa própria doença.

O Brasil é um país enorme, mas mesmo assim são muitos os homens que não possuem um teto para morar, ou um pedaço de chão para cultivar. Esse paradoxo se mistura a um outro, pois esse mesmo país que abriga 190 milhões de cabeças humanas, e deixa milhões sem ter onde dormir ou cair morto é o mesmo país que oferece terra, água, abrigo, alimento e assistência médica a mais 200 milhões de cabeças que não são humanas, mas são animais.

Animais não humanos, que vivem nas terras do mundo, e vem e vão como estalos errantes. Hoje se entra em setembro, e não passará o mês sem que morram aos milhares sem fim as galinhas 'adultas' que, ontem ainda, saíram do ovo. Tiveram suas vidas acachapadas, seus anos reduzidos a pobres semanas de clausura. Cruzaram o Brasil sobre rodas de enormes carretas, no vento, no sol, no frio e na chuva, e ninguém viu. Seus corpos banhados com óleo e queimados na chapa, servidos nos pratos, tragados aos tratos digestórios dos homens, e ninguém as notou. Setembro será mais um mês. Um Rio Araguaia de sangue de aves correu no país, e que venha outubro em seus ventos de morte.

Na Europa os homens têm bom coração. Se compadecem das barrigas em fome, e chegam a pagar ao Brasil para que faça mais soja - nem que para isso precise tornar em cinzas os verdes frondosos da nossa Amazônia. Barrigas tem fome e precisam comer. São vacas e bois aos milhares, que, desafortunados, não contam com o pasto abundante do nosso país. Mas contam com a soja abundante, com o cheiro da fumaça do cerrado que agora é deserto, e vai de navio até suas bocas. Comida importada. Até que não são tão invisíveis assim.

$\mathrm{O}$ mundo tem cheiro de diesel. Diesel e peido. O peido assassino que lhe queima os cabelos das narinas até pode ter vindo do seu colega de trabalho. Mas o peido potente, o metano que queima a camada de ozônio e transforma o planeta em estufa, é obra dos cus invisíveis. A usina de flato animal tem filiais espalhadas nos quatro cantos da terra, e consegue poluir os ares mais do que todos veículos a motor desse mundo, é o que dizem as Nações Unidas. Produção diuturna de gases invisíveis, só não tão invisíveis quanto os seus próprios emissores. 
Decapitação, eletrocussão, esquartejamento, degolação. Vivemos o enredo de um filme de terror onde o sangue não é de tomate. Um festival doentio de mortes, cuja variedade e criatividade sádica põe catatônicos os mais bizarros roteiristas de todos os tempos. Caldeiras de água fervente para o mergulho dos vivos, serras para extirpar bicos, para arrancar testículos, máquinas de empurrar maisena e gordura de porco direto nos fígados, e um imenso triturador, para transformar os nascidos defeituosos, ainda vivos, em ração para os demais. São estes alguns dos itens da trama de Os mais invisíveis do mundo, o thriller que nunca saiu de cartaz, e que ninguém se propõe a assistir. 